Volume 13, No. 1, June 2020

\title{
ANALYSIS OF THE ACTION OF RACISM ON THE HELP FILM DIRECTED BY TATE TAYLOR
}

\author{
Damara Komala Padma, Senja Yustitia, Siti Fatonah \\ Department of Communication Science \\ Faculty of Social and Political Sciences, UPN "Veteran" Yogyakarta \\ Email: damarakomala@gmail.com
}

\begin{abstract}
Racism is a problem that has existed throughout the world since ancient times. Indonesia also does not escape the issue of racism. From the small issues that we did not realize until the big problems involving many parties. This racism makes the atmosphere uncomfortable and conducive if it has to involve many parties. Therefore, many filmmakers who try to raise the theme of racism become a film. This study's problem is how the movie, especially those related to forms of racism. From the formulation of this problem, this study aims to find out the contents of the film The Help, especially those related to forms of acts of racism. This study uses the content analysis method with the data validity technique is reliability testing. Based on the results of the study, it is known that the film The Help contains many acts of racism. In the scene of discrimination and prejudice dominated by actions taken by white figures to blacks. The response to this attitude of racism gave rise to hatred also fear-the scene dominated by black characters' treatment to white people. The scene of the rules made for black characters also appeared. At the same time, violence and prohibition are dominated by actions to fellow race. The act of racism appears more in the middle part of the film.
\end{abstract}

Keywords: Content Analysis, Racism, Discrimination, The Help, Film

\section{INTRODUCTION}

As a propaganda tool, the film is closely linked to achieving national and community objectives. It is related to the view that the film has a range, realism, emotional influence, and great popularity. Confound efforts messages with entertainment development has long been applied in literature and drama. Still, the new elements in the film have advantages in terms of its ability to reach many people quickly. The ability to manipulate reality appears with a photographic message without losing credibility (McQuail, 2011).
One of the most dominant propaganda presented in films is racism, such as the tribal war in Africa, which is told in the film Hotel Rwanda in 2004. It is based on real events in 1994. There was a massacre between the Hutu and Tutsi tribes, where this conflict resulted in nearly one million people being killed. Africa is known for its minimal tolerance between tribes. Not only in Africa but racism even throughout the world.

The sad reality of racism is that racism has already existed throughout the world since the beginning. History is full of examples. In the past, African-Americans 
were forced to stay behind while riding buses. Jews were required to wear a yellow David badge. Japanese-Americans were isolated in tents during World War 2, and Indian-Americans were seized from their land the African society divided by race. Today we see the manifestation of racism in the form of graffiti (graffiti on the wall), which insults race, destruction of property rights, intimidation, and even physical violence. People are also taking action blatant racism, such as insults or tell jokes about ethnicity.

In Indonesia, we know it has a large population and has a variety of cultures, ethnicities, races, and religions. According to the Central Statistics Agency (BPS), Indonesia's population in 2017 reached 262 million. There are more than 300 ethnic groups or ethnic groups in Indonesia or precisely 1,340 ethnic groups, according to the 2010 BPS census (BPS, 2018). With so many differences, of course, it doesn't always run smoothly side by side. Sometimes there is a little upheaval due to this difference. Like other countries, Indonesia is also not immune to the problem of racism. From small issues that sometimes we don't realize have been racist to massive problems and involve many parties. The beginning of racism stems from an attitude where we assume that "they" are different from "us." Many cases of discrimination in Indonesia, among which are very well known, are the May 1998 riots. These riots were racial riots against ethnic Chinese, where at that time, many Indonesians of Chinese descent were killed, tortured, and raped.

About racism, The Help is one of the films that raise racism as a theme directed by Tate Taylor. The film, set in the 60s, presents a simple example of discrimination, namely racism by homemakers in Jackson, Mississippi, against their black servants. With so many films taking up the theme of racism, researchers see that the movie The Help is brave enough to reveal racism in the United States and movies that depict real life. Hence, the writer decides to choose the film The Help as an object of this research.

This research aims to find out the film's contents The Help related explicitly to forms of racism. In obtaining this goal, researchers used McLemore's racism theory and Carmichael and Hamilton's racism concepts to make units of analysis. 


\section{METHOD}

In this study, researchers used quantitative descriptive content analysis methods. According to Krippendorff (Krippendorff, 1993), content analysis is a technique for making inferences that can be replicated and valid by paying attention to the context. The content analysis model not only knows how the contents of the news text, but how the message conveyed so that it can see the hidden meaning of a text (Eriyanto, 2011). The object of this research is the act of racism in the film The Help. The data analysis technique used is the reliability test. To see whether the data used in this analysis are appropriate, researchers used the intercoder reliability method, namely the Holsti formula (Eriyanto, 2011), using nominal data in the form of a percentage at the level of equality over the categories used.

\section{DISCUSSION}

Here are the results of research based on the count on each unit of analysis and categorization predetermined.

The results of table 1 about individual racism scenes with discrimination categorization can be concluded that the discrimination that appears dominant in the film The Help is a scene of discrimination committed by white figures to black figures with a percentage of $84.21 \%$. This scene of discrimination by white statistics is the most presented in films. Out of 57 discrimination scenes, 48 of them were discrimination scenes committed by white figures to black

Table 1

Unit Analysis of Individual Racism Scenes Related to Discrimination

\begin{tabular}{|c|c|c|c|c|c|c|c|c|}
\hline & \multicolumn{6}{|c|}{ Sub Categorization } & \multirow{2}{*}{\multicolumn{2}{|c|}{ Amount }} \\
\hline & \multicolumn{2}{|c|}{$\begin{array}{l}\text { Beginning } \\
\text { of Film }\end{array}$} & \multicolumn{2}{|c|}{$\begin{array}{l}\text { Middle Part } \\
\text { of Film }\end{array}$} & \multicolumn{2}{|c|}{$\begin{array}{l}\text { End of } \\
\text { Film }\end{array}$} & & \\
\hline Categorization & $\mathrm{F}$ & $\%$ & $\mathrm{~F}$ & $\%$ & $\mathrm{~F}$ & $\%$ & $\mathrm{~F}$ & $\%$ \\
\hline $\begin{array}{l}\text { The scene } \\
\text { discrimination by white } \\
\text { figures against black } \\
\text { people. }\end{array}$ & 12 & 21,05 & 36 & 63,16 & 0 & 0,00 & 48 & 84,21 \\
\hline $\begin{array}{l}\text { The scene } \\
\text { discrimination by black } \\
\text { figures against white } \\
\text { people. }\end{array}$ & 0 & 0,00 & 3 & 5,26 & 0 & 0,00 & 3 & 5,26 \\
\hline $\begin{array}{l}\text { Others are not included } \\
\text { above. }\end{array}$ & 1 & 1,75 & 5 & 8,77 & 0 & 0,00 & 6 & 10,53 \\
\hline Amount & 13 & 22,81 & 44 & 77,19 & 0 & 0,00 & 57 & 100 \\
\hline
\end{tabular}


figures, including 12 scenes, each appearing at the film's opening and 36 scenes in the middle of the film.

Table 2 results about individual racism scenes, including prejudice categorization, can be concluded that the scenes that appear to dominate in the film The Help are negative prejudice scenes performed by white figures to black figures with a percentage of $33.33 \%$. Scenes that show white skin with negative prejudices against blacks appear in the film The Help. The frequency of occurrence is 13 times out of 39 prejudice scenes, with 7 scenes each appearing in the opening movie with a percentage of $17.95 \%$. Five scenes in the middle of the film with a percentage of $12.82 \%$. One scene on the cover with a percentage of $2,56 \%$.
Based on table 3 below, the number of violent scenes is relatively high. The visible number of scenes that appear in the film is 116 scenes. In this film, there are many scenes of violence, both physical violence, and verbal violence. It can be seen that from the categorization of violence, the scenes with the highest frequency of occurrence are insulting scenes (verbal violence) committed by the same race with a percentage of $24.14 \%$. The number of scenes from this sub-categorization was 28 scenes from 116 scenes with a categorization of violence that appeared in the film. There are 28 scenes divided into 12 scenes, with $10.34 \%$ at the beginning of the film. Sixteen scenes with a percentage of $13.79 \%$ in the middle of the film.

Table 2

Unit Analysis of Individual Racism Scenes Related to Prejudice

\begin{tabular}{|l|c|c|c|c|c|c|c|c|}
\hline & \multicolumn{5}{|c|}{ Sub Categorization } & \multicolumn{2}{c|}{ Amount } \\
\cline { 2 - 9 } & $\begin{array}{c}\text { Beginning } \\
\text { of Film }\end{array}$ & \multicolumn{2}{|c|}{$\begin{array}{c}\text { Middle Part } \\
\text { of Film }\end{array}$} & \multicolumn{2}{|c|}{$\begin{array}{c}\text { End of } \\
\text { Film }\end{array}$} & \multicolumn{2}{c|}{ Am } \\
\hline Categorization & F & $\%$ & F & $\%$ & F & $\%$ & F & $\%$ \\
\hline $\begin{array}{l}\text { The negative prejudice } \\
\text { scene of a black figure to } \\
\text { a white figure. }\end{array}$ & 1 & 2,56 & 8 & 20,51 & 0 & 0,00 & 9 & 23,08 \\
\hline $\begin{array}{l}\text { The scene of negative } \\
\text { prejudice white figures to } \\
\text { blacks. }\end{array}$ & 7 & 17,95 & 5 & 12,82 & 1 & 2,56 & 13 & 33,33 \\
\hline $\begin{array}{l}\text { The scene of positive } \\
\text { prejudice black figures to } \\
\text { white skin. }\end{array}$ & 3 & 7,69 & 2 & 5,13 & 0 & 0,00 & 5 & 12,82 \\
\hline $\begin{array}{l}\text { The scene of positive } \\
\text { prejudice of white figures } \\
\text { to blacks. }\end{array}$ & 0 & 0,00 & 0 & 0,00 & 1 & 2,56 & 1 & 2,56 \\
\hline $\begin{array}{l}\text { Others are not included } \\
\text { above. }\end{array}$ & 4 & 10,26 & 7 & 17,95 & 0 & 0,00 & 11 & 28,21 \\
\hline Amount & 15 & 38,46 & 22 & 56,41 & 2 & 5,13 & 39 & 100 \\
\hline
\end{tabular}


Table 3

Unit Analysis of Individual Racism Scenes Related to Violence

\begin{tabular}{|c|c|c|c|c|c|c|c|c|}
\hline & \multicolumn{6}{|c|}{ Sub Categorization } & \multirow{2}{*}{\multicolumn{2}{|c|}{ Amount }} \\
\hline & \multicolumn{2}{|c|}{$\begin{array}{l}\text { Beginning of } \\
\text { Film }\end{array}$} & \multicolumn{2}{|c|}{$\begin{array}{l}\text { Middle Part } \\
\text { of Film }\end{array}$} & \multicolumn{2}{|c|}{$\begin{array}{l}\text { End of } \\
\text { Film }\end{array}$} & & \\
\hline Categorization & $\mathrm{F}$ & $\%$ & $F$ & $\%$ & $\mathrm{~F}$ & $\%$ & F & $\%$ \\
\hline $\begin{array}{l}\text { The scene of beating (physical } \\
\text { violence) by the white figure on a } \\
\text { black. }\end{array}$ & 0 & 0,00 & 1 & 0,86 & 0 & 0,00 & 1 & 0,86 \\
\hline $\begin{array}{l}\text { The scenes of hitting (physical } \\
\text { violence) by black figures against } \\
\text { white people. }\end{array}$ & 0 & 0,00 & 0 & 0,00 & 0 & 0,00 & 0 & 0,00 \\
\hline $\begin{array}{l}\text { The hitting scenes (physical violence) } \\
\text { were carried out by the same race. }\end{array}$ & 0 & 0,00 & 3 & 2,59 & 0 & 0,00 & 3 & 2,59 \\
\hline $\begin{array}{l}\text { The pushing scenes (physical } \\
\text { violence) perpetrated by white } \\
\text { figures on blacks. }\end{array}$ & 0 & 0,00 & 0 & 0,00 & 0 & 0,00 & 0 & 0,00 \\
\hline $\begin{array}{l}\text { The pushing scenes (physical } \\
\text { violence) by black figures against } \\
\text { white people. }\end{array}$ & 0 & 0,00 & 0 & 0,00 & 0 & 0,00 & 0 & 0,00 \\
\hline $\begin{array}{l}\text { The pushing scenes (physical } \\
\text { violence) are carried out by the same } \\
\text { race. }\end{array}$ & 0 & 0,00 & 4 & 3,45 & 0 & 0,00 & 4 & 3,45 \\
\hline $\begin{array}{l}\text { The screaming scene (verbal } \\
\text { violence) is committed by white } \\
\text { figures to black people. }\end{array}$ & 1 & 0,86 & 6 & 5,17 & 0 & 0,00 & 7 & 6,03 \\
\hline $\begin{array}{l}\text { The screaming scene (verbal } \\
\text { violence) by a black character to a } \\
\text { white person. }\end{array}$ & 0 & 0,00 & 3 & 2,59 & 0 & 0,00 & 3 & 2,59 \\
\hline $\begin{array}{l}\text { The screaming scenes (verbal abuse) } \\
\text { committed by the same race. }\end{array}$ & 7 & 6,03 & 17 & 14,66 & 0 & 0,00 & 24 & 20,69 \\
\hline $\begin{array}{l}\text { The insulting scenes (verbal abuse) } \\
\text { perpetrated by white figures on } \\
\text { blacks. }\end{array}$ & 1 & 0,86 & 9 & 7,76 & 1 & 0,86 & 11 & 9,48 \\
\hline $\begin{array}{l}\text { The insulting acene (verbal abuse) is } \\
\text { committed by a black character to a } \\
\text { white person. }\end{array}$ & 4 & 3,45 & 8 & 6,90 & 1 & 0,86 & 13 & 11,21 \\
\hline $\begin{array}{l}\text { The insulting scenes (verbal abuse) } \\
\text { perpetrated by the game race. }\end{array}$ & 12 & 10,34 & 16 & 13,79 & 0 & 0,00 & 28 & 24,14 \\
\hline Others are not included above. & 1 & 0,86 & 20 & 17,24 & 1 & 0,86 & 22 & 18,97 \\
\hline Amount & 26 & 22,41 & 87 & 75,00 & 3 & 2,59 & 116 & 100 \\
\hline
\end{tabular}

Source: Primary Data 
It can be seen that this hate analysis unit is widely displayed or appears in The Help. Seen with 117 scenes is the highest number compared to other categories. Table 4 below shows that the scene with the highest percentage is the scene showing the hatred of black figures to white figures with a portion of $45.30 \%$. While the frequency of occurrence is 53 scenes from 117. Nine scenes at the beginning $(7,69 \%)$, forty-one scenes in the middle $(35,04 \%)$, and three scenes at the closing of The Help (2,56\%).

Scenes that show black hatred on white skin here are all scenes that show black characters hate or dislike the treatment of whites or the people themselves. The percentage of hatred of black people on white skin is very high when compared to the others. At the beginning of the film, nine scenes have appeared showing hate. In the conflict section, there were even more, as many as 41 scenes. It shows that black people either hated or disliked the treatment of white people. Often in this film blacks are treated arbitrarily and demeaned; this hateful scene often appears in the film as a manifestation that blacks do not like their treatment.

From table 5, it can be concluded that the most dominant scene is a scene that shows a black figure afraid of white figures

Table 4

Unit Analysis of Individual Racism Scenes Related to Resentment

\begin{tabular}{|l|c|c|c|c|c|c|c|c|}
\hline & \multicolumn{5}{|c|}{ Sub Categorization } & \multicolumn{2}{c|}{} \\
\cline { 2 - 9 } & \multicolumn{2}{|c|}{$\begin{array}{c}\text { Beginnin } \\
\text { g of Film }\end{array}$} & $\begin{array}{c}\text { Middle part } \\
\text { of film }\end{array}$ & \multicolumn{2}{|c|}{$\begin{array}{c}\text { End of } \\
\text { Film }\end{array}$} & \multicolumn{2}{c|}{ Amount } \\
\hline Categorization & F & $\%$ & F & $\%$ & F & $\%$ & F & $\%$ \\
\hline $\begin{array}{l}\text { The scenes that show } \\
\text { hatred of white figures } \\
\text { against blacks. }\end{array}$ & 1 & 0,85 & 16 & 13,68 & 6 & 5,13 & 23 & 19,66 \\
\hline $\begin{array}{l}\text { The scenes that show } \\
\text { hatred of black figures } \\
\text { against whites. }\end{array}$ & 9 & 7,69 & 41 & 35,04 & 3 & 2,56 & 53 & 45,30 \\
\hline $\begin{array}{l}\text { The scenes that show } \\
\text { hatred towards the same } \\
\text { race. }\end{array}$ & 11 & 9,40 & 30 & 25,64 & 0 & 0,00 & 41 & 35,04 \\
\hline $\begin{array}{l}\text { Others are not included } \\
\text { above. }\end{array}$ & 0 & 0,00 & 0 & 0,00 & 0 & 0,00 & 0 & 0,00 \\
\hline Amount & 21 & 17,95 & 87 & 74,36 & 9 & 7,69 & 117 & 100 \\
\hline
\end{tabular}




\section{Tabel 5}

Unit Analysis of Individual Racism Scenes Related to Fear

\begin{tabular}{|l|c|c|c|c|c|c|c|c|}
\hline & \multicolumn{5}{|c|}{ Sub Categorization } & \multicolumn{3}{c|}{} \\
\cline { 2 - 8 } & $\begin{array}{l}\text { Beginning } \\
\text { of Film }\end{array}$ & $\begin{array}{c}\text { Middle Part } \\
\text { of Film }\end{array}$ & \multicolumn{2}{|c|}{$\begin{array}{c}\text { End of } \\
\text { Film }\end{array}$} & \multicolumn{2}{c|}{} \\
\hline Categorization & F & $\%$ & F & $\%$ & F & $\%$ & F & $\%$ \\
\hline $\begin{array}{l}\text { Scenes that show black } \\
\text { figures are afraid of white } \\
\text { figures. }\end{array}$ & 1 & 1,72 & 20 & 34,48 & 5 & 8,62 & 26 & 44,83 \\
\hline $\begin{array}{l}\text { Scenes that show white } \\
\text { figures are afraid of black } \\
\text { people. }\end{array}$ & 0 & 0,00 & 5 & 8,62 & 3 & 5,17 & 8 & 13,79 \\
\hline $\begin{array}{l}\text { Scenes that show } \\
\text { characters afraid of the } \\
\text { same race. }\end{array}$ & 1 & 1,72 & 2 & 3,45 & 1 & 1,72 & 4 & 6,90 \\
\hline $\begin{array}{l}\text { Others are not included } \\
\text { above. }\end{array}$ & 0 & 0,00 & 19 & 32,76 & 2 & 3,45 & 21 & 36,21 \\
\hline Amount & 1 & 1,72 & 46 & 79,31 & 11 & 18,97 & 58 & 100 \\
\hline
\end{tabular}

with a percentage of $44.83 \%$. The frequency of scenes showing black characters is scared of white characters in the film The Help of 26 scenes from a total of 58 scenes in the fear analysis sub-unit. The details of 26 scenes consist of 1 scene $(1,72 \%)$ at the beginning, 20 scenes $(34,48 \%)$ in the middle, and five scenes $(8,62 \%)$ at the end of the film.

From table 6 below, it can be seen and concluded that the highest scenes that appear in this categorization are two scenes. In this categorization, there are not many scenes that occur, so that the total frequency of appearance is only 11 scenes. The rules here are written regulations made by the government for both races. The first scene is a scene that displays regulations or rules made for black characters with a percentage of $45.45 \%$ or with a frequency of 5 scenes from a total of 11 scenes. These five scenes only appear in the middle of the film. Given that blacks here are a minority race, it is not surprising that blacks have many rules. These rules are rules that limit the space of blacks and separate blacks and whites.

From table 7 below, it can be seen that in this analysis, the sub-unit is an analysis sub-unit with the least frequency of occurrence of scenes when compared with other sub-units of analysis. The number of frequencies occurring in this subunit of analysis is only eight scenes. It can be seen that the most dominant scenes in this categorization are scenes where someone forbids to do or do something by the same 
Table 6

Structural Racism Scene Analysis Unit Related to Rules

\begin{tabular}{|l|c|c|c|c|c|c|c|c|}
\hline & \multicolumn{5}{|c|}{ Sub Categorization } & \multicolumn{3}{c|}{} \\
\cline { 2 - 9 } & $\begin{array}{c}\text { Beginning } \\
\text { of Film }\end{array}$ & $\begin{array}{c}\text { Middle } \\
\text { Part of } \\
\text { Film }\end{array}$ & \multicolumn{2}{c|}{$\begin{array}{c}\text { End of } \\
\text { Film }\end{array}$} & \multicolumn{2}{c|}{ Amount } \\
\hline Categorization & F & $\%$ & F & $\%$ & F & $\%$ & F & $\%$ \\
\hline $\begin{array}{l}\text { The scene rules or rules } \\
\text { that are made for black } \\
\text { figures. }\end{array}$ & 0 & 0,00 & 5 & 45,45 & 0 & 0,00 & 5 & 45,45 \\
\hline $\begin{array}{l}\text { The scene regulations are } \\
\text { made for white figures. }\end{array}$ & 1 & 9,09 & 0 & 0,00 & 0 & 0,00 & 1 & 9,09 \\
\hline $\begin{array}{l}\text { The scenes of rules are } \\
\text { made for both races. }\end{array}$ & 0 & 0,00 & 5 & 45,45 & 0 & 0,00 & 5 & 45,45 \\
\hline $\begin{array}{l}\text { Others are not included } \\
\text { above }\end{array}$ & 0 & 0,00 & 0 & 0,00 & 0 & 0,00 & 0 & 0,00 \\
\hline Amount & 1 & 9,09 & 10 & 90,91 & 0 & 0,00 & 11 & 100 \\
\hline
\end{tabular}

race. The percentage is $50 \%$ with the frequency of appearances in the film The Help of 4 scenes out of 8 scenes. All four scenes appear in the middle of the film.

After the research results are known, researchers juxtapose these results with the theory of discrimination put forward by McLemore. Racism here is a behavior that limits and divides certain groups. The discrimination usually begins with prejudices or assumptions that are believed by someone. McLemore said that this discrimination was influenced by three things: situational pressures, group gains, and institutional structure.

This factor is attributed to the film The Help often occurs when individuals are in a group or in a public place, where they must position themselves in the group. However, he has a different view from them. It can be seen from the research results in which the percentage of scenes of discrimination committed by whites to blacks is very high. Scenes included in this unit of analysis tend to show individuals discriminating but not their will. But encouragement from the surrounding environment.

The second factor that can affect discrimination is the existence of group gains. This group gain is an attitude in which dominant groups fear that migrants will take their land. The second factor also appears a lot in the research results in the analysis unit discrimination white scenes to black. The dominant group discriminates so 
Table 7

Unit of Analysis of Structural Racism Scenes Regarding Prohibition

\begin{tabular}{|l|c|c|c|c|c|c|c|c|}
\hline & \multicolumn{5}{|c|}{ Sub Categorization } & \multicolumn{3}{c|}{} \\
\cline { 2 - 7 } & $\begin{array}{l}\text { Beginning } \\
\text { of Film }\end{array}$ & $\begin{array}{c}\text { Middle Part } \\
\text { of Film }\end{array}$ & \multicolumn{2}{|c|}{$\begin{array}{c}\text { End of } \\
\text { Film }\end{array}$} & \multicolumn{2}{c|}{ Amount } \\
\hline Categorization & F & $\%$ & F & $\%$ & F & $\%$ & F & $\%$ \\
\hline $\begin{array}{l}\text { Scenes performed by } \\
\text { white figures prohibit } \\
\text { black figures from doing } \\
\text { or doing anything. }\end{array}$ & 0 & 0,00 & 1 & 12,50 & 0 & 0,00 & 1 & 12,50 \\
\hline $\begin{array}{l}\text { Scenes performed by } \\
\text { black figures prohibit } \\
\text { white figures from doing } \\
\text { or doing anything. }\end{array}$ & 0 & 0,00 & 3 & 37,50 & 0 & 0,00 & 3 & 37,50 \\
\hline $\begin{array}{l}\text { Scenes that show } \\
\text { someone forbid to do or } \\
\text { do something by the same } \\
\text { race. }\end{array}$ & 0 & 0,00 & 4 & 50,00 & 0 & 0,00 & 4 & 50,00 \\
\hline $\begin{array}{l}\text { Others are not included } \\
\text { above }\end{array}$ & 0 & 0,00 & 0 & 0,00 & 0 & 0,00 & 0 & 0,00 \\
\hline Amount & 0 & 0,00 & 8 & 100,00 & 0 & 0,00 & 8 & 100 \\
\hline
\end{tabular}

\section{Source: Primary Data, 2018}

that it benefits the group, as shown in the film The Help, where black only has a small salary. Black people do not get high jobs; for example, in the company where Skeeter works, there is no single black person who works there.

The last factor influencing discrimination is an institutional structure. This factor is related to the group gains used to create a system that they have and maintain their dominant position. The white race is the dominant race in this film; therefore, they form legislation that regulates their work as prevalent and minority positions.
In addition to the discrimination theory above, to find out the contents of this film about racism, researchers used the concept of racism proposed by Carmichael and Hamilton (Liliweri, 2005). Researchers also use the idea of racism as a guide in creating units of analysis and categorization. Carmichael and Hamilton say that there are two types of racism, namely individual racism and institutional racism. Individual racism contains discrimination, prejudice, violence, hatred, and fear. At the same time, institutional racism includes rules and prohibitions. Of these two types of racism, researchers 
dissect them again into categories according to these types.

\section{CONCLUSION}

The scene of discrimination that most often appears in the film is the scene of discrimination committed by white and black figures. It is because whites are the dominant group trying to maintain their position by discriminating. The category of prejudice that most often appears is the negative prejudice scene of white figures to blacks. It is not surprising because white figures who have negative assumptions about blacks are then forwarded to discriminatory attitudes. Scenes of violence in individual racism that have the highest percentage and often appear in the film The Help are scenes of insults (verbal violence) committed by the same race. The unique finding is that there are so many scenes in the film that show insulting other characters of the same race. The hate category is the category with the most scenes. This scene of hatred is a response to the existing racism. The highest percentage is in the scene that shows the contempt of black figures to white people. It is because of the white attitude which always discriminates against blacks. The category of fear as a form of reaction to a threat to a group of people appears in the scene showing a black character afraid of a white character. It is by the black race who are scared of whites because they are often oppressed.

Regulatory scenes of structural racism originate from the government and are in the form of rules or legislation. Many scenes that appear are scenes of laws or regulations made for black figures. The black race causes this as the majority race wants to control the whites to make the rules. This prohibition scene is part of structural racism, but the study results show that the most emergent is the scene where someone forbids to do or do something by the same race. Fellow whites and blacks carry out many scenes that appear. Many acts of racism appear in the middle of the film.

\section{REFERENCE}

BPS. (2018). BPS. Retrieved from BPS: https://www.bps.go.id/statictable/2 009/02/20/1267/pendudukindonesia-menurut-provinsi-19711980-1990-1995-2000-dan2010.html

Eriyanto. (2011). Analisis Isi: Pengantar Metodologi Untuk Penelitian ilmu Komunikasi dan Ilmu-Ilmu Sosial Lainnya. Jakarta: Kencana Prenada Media.

Krippendorff, K. (1993). Analisis Isi: Pengantar Teori dan Metodologi. Jakarta: Citra Niaga Rajawali Pers.

Liliweri, A. (2005). Prasangka dan Konflik; Komunikasi Lintas Budaya Masyarakat Multikultur. Yogyakarta: LKiS. 
McQuail, D. (2011). Teori Komunikasi Massa: Suatu Pengantar. Jakarta: Citra Niaga Rajawali Pers. 